IRA-INTERNATIONAL JOURNAL OF MANAGEMENT \& SOCIAL SCIENCES

(A scholarly peer reviewed and refereed publication of Institute of Research Advances)

ISSN 2455-2267 Vol.02, Issue 03 (March 2016)

DOI: http://dx.doi.org/10.21013/10.21013/jmss.v2.n3.p2

\title{
A study on the imminence of the global financial crisis
}

\author{
Dave Jonathan \\ University of Naples Federico II, Napoli, Italy.
}

\begin{abstract}
The financial crisis has been a concern for everyone in the world community especially the central bank's governors of nations worldwide. Post 2008 sub prime crisis is no more over. It is there and it can be calculated in present terms too. This paper, will analyze the instances which can easily predict the expected existence of the financial crisis globally.
\end{abstract}

Keywords: Financial Crisis, Post 2008 financial crisis, world economy, central banking, economic slowdown

\section{Discussion}

In the course of the most recent six months, worldwide money related solidness dangers expanded as an aftereffect of the accompanying advancements:

To start with, macroeconomic dangers have risen, mirroring a weaker and more unverifiable viewpoint for development and expansion, and more quelled feeling. These dangers were highlighted yesterday at the World Economic Outlook question and answer session.

Second, falling product costs and worries about China's economy have put weight on developing markets and propelled economy credit markets.

At last, trust in strategy footing has slipped, in the midst of worries about the capacity of overburdened money related approaches to counterbalance the effect of higher monetary and political dangers.

Prior in the year, markets responded adversely to these improvements. Worldwide values dove; unpredictability climbed strongly; talk of subsidence in cutting edge economies expanded; and bank value costs went under restored weight.

Today the circumstance in business sectors shows up essentially better contrasted with the lows of mid-February. Value markets have recuperated a lot of their misfortunes and oil costs are higher, while unpredictability has died down. This change tailed some better news on the monetary front, and additionally heightened strategy activities by the European Central Bank, and a more mindful position toward raising rates by the U.S. Central bank. China has additionally ventured up endeavors to fortify its approach system to support development and balance out the conversion scale.

A key question that this Global Financial Stability Report release locations is whether the turmoil that we have seen over the previous months is presently securely behind us, or is it a notice flag that 
all the more should be finished? I trust it is the last mentioned: all the more should be done to secure worldwide steadiness.

Much is in question. Extra measures are expected to convey a more adjusted and powerful approach blend. If not, showcase turmoil may repeat and strengthen, and could make a poisonous input circle of delicate certainty, weaker development, more tightly money related conditions, and rising obligation troubles. This could tip the worldwide economy into monetary and money related stagnation. In such a situation, we appraise that world yield could fall by just about 4 percent, in respect to our standard projections, throughout the following five years (Figure 1). This would be generally identical to swearing off one year of worldwide development.

\section{Figure 1. What's at Stake?}

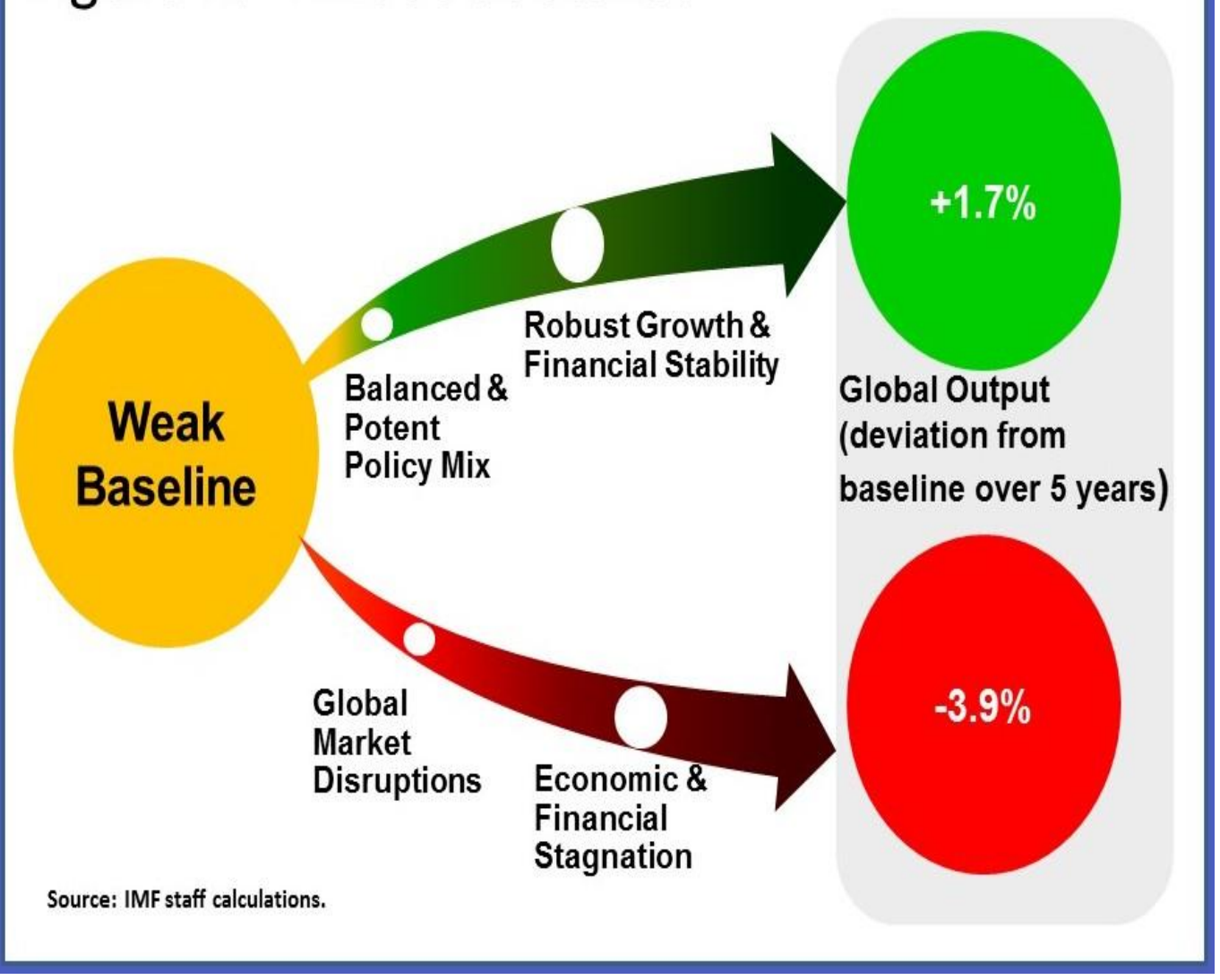

So what should be finished? We have to go past the norm. We require an aggregate way to deal with policymaking to handle a triad of worldwide difficulties. These are the same difficulties that I underscored six months prior, to be specific emergency legacy issues still unaddressed in cutting edge economies, lifted vulnerabilities in developing markets, and systemic business sector liquidity dangers. The business sector turbulence we encountered recently is a capable indication of this unfinished business.

Give me a chance to talk about now the difficulties confronting propelled economies and developing markets, and what should be done to address them. Handling these difficulties will empower to extend world yield by up to 1.7 percent, with respect to the gauge, throughout the following five years (Figure 1). That resembles securing an extra a large portion of a year of worldwide development.

The main test to handle is emergency legacies in cutting edge economies, especially banks, as they assume a key part in financing the economy. Banks in cutting edge economies are currently 
significantly more secure. Yet they went under noteworthy business sector weights toward the begin of the year, as the financial standpoint debilitated and turned out to be more indeterminate.

Yet, banks likewise confront critical basic difficulties in adjusting to the new post-emergency substances that keep on depressing their benefit. Numerous banks in cutting edge economies face huge plan of action difficulties. We gauge that these banks represent around 15 percent of bank resources in cutting edge economies. In the euro zone, market weights likewise highlight long standing legacy issues. Hoisted nonperforming advances desperately should be handled utilizing a far reaching methodology and abundance bank limit- to be specific, an excessive number of bankswill must be tended to after some time. Europe should likewise finish the managing an account union and set up a typical store ensure plan.

The second key test to handle is from developing markets. The sharp fall in thing costs has exacerbated both corporate and sovereign vulnerabilities, keeping monetary and money related dangers raised. Following quite a while of developing obligation, rising economies confront a troublesome blend of slower development, more tightly credit conditions, and unstable capital streams. In this way, numerous economies have demonstrated amazing versatility to this troublesome environment, on account of the reasonable utilization of cradles aggregated amid the blast years. Yet, cushions are draining rapidly, with a few nations coming up short on space to move.

As the strength of the corporate area falls apart, particularly in ware sending out nations and thing related divisions, renegotiating weights may turn out to be more intense. This can create overflows to the legislature, the same number of weaker corporates are state possessed. Bank cushions are for the most part satisfactory in numerous developing markets however might be tried by expanding nonperforming advances. These interlinkages underscore the significance of close checking of corporate vulnerabilities, quick and straightforward acknowledgment and administration of nonperforming resources, and reinforcing the versatility of banks.

Among rising economies, the most critical one is China. China keeps on exploring a mind boggling move to a slower and more adjusted pace of development and a more market-based money related framework. The Chinese powers have propelled changes however the move remains characteristically mind boggling.

Here, the corporate-bank nexus is likewise basic. In spite of advancement on financial rebalancing, corporate wellbeing in China is declining because of moderating development and lower productivity. This is reflected in the rising offer of obligation held by firms that don't gain enough to cover their advantage installments. This measure, which we name "obligation at danger," has expanded to 14 percent of the obligation of recorded Chinese organizations, dramatically multiplying following 2010.

Expanded strains in Chinese firms are vital to Chinese banks. This report gauges that corporate bank advances possibly at danger in China add up to practically US\$1.3 trillion. These advances could decipher into potential bank misfortunes of around 7 percent of GDP. This number may appear to be huge however it is sensible, given China's bank and approach supports and proceeded with solid development in the economy. Similarly critical, the Chinese powers know about these vulnerabilities and are putting set up measures to manage the over obliged corporates. Yet, the greatness of these vulnerabilities requires an eager arrangement motivation: 1) tending to the corporate obligation overhang, 2) reinforcing banks, and 3) redesigning the supervisory structure to bolster an undeniably complex money related framework. 


\section{Conclusion}

We have to work by and large to reinforce development and money related security past the present pattern. This is possible. Policymakers need to convey a more adjusted and intense arrangement blend that goes past proceeded with overreliance on financial strategy. Money related arrangement stays urgent however can't be the main amusement nearby. All around outlined basic changes and development cordial and steady financial strategies are vital. What's more, more grounded money related approaches that further upgrade versatility must be placed set up. At the worldwide level, the budgetary administrative change plan should likewise be finished and executed-including for nonbanks. These activities will convey equalization to the approach blend, and together will make arrangements more powerful and compelling.

\section{References}

Boddy, C. R. (2011). The corporate psychopaths theory of the global financial crisis. Journal of Business Ethics, 102(2), 255-259.

Cossiga, G. A. (2015). The Instability of Economic Systems and speculative market: The case of China. Scholedge International Journal of Management \& Development, 2(9), 53-69.

Crotty, J. (2009). Structural causes of the global financial crisis: a critical assessment of the "new financial architecture'. Cambridge Journal of Economics, 33(4), 563-580.

El El Namaki, M. S. S. (2015). Strategies For Offense And Defense In Global Capital Markets. Scholedge International Journal of Management \& Development, 2(5), 68-74.

Fidrmuc, J., \& Korhonen, I. (2010). The impact of the global financial crisis on business cycles in Asian emerging economies. Journal of Asian Economics, 21(3), 293-303.

Frank, N., \& Hesse, H. (2009). Financial spillovers to emerging markets during the global financial crisis (No. 9-104). International Monetary Fund.

Obstfeld, M., \& Rogoff, K. (2009). Global imbalances and the financial crisis: products of common causes.

Rudd, K. (2009). The global financial crisis. Monthly, The, (Feb 2009), 20.

Scott, K. D. (2014). Global Financial Crises. 